\title{
Optimization of Central Composite Design of Ferric Reducing Antioxidant Power from Cocoa (Theobroma cacao) Shell using Ultrasound-assisted Technique
}

\author{
Md Yusof A. H, Abd Gani S. S, Zaidan U. H, Halmi M. I. E, Abdul Wahab N
}

\begin{abstract}
Cocoa (Theobroma cacao) shell is waste product discarded from the cocoa industry. About $75 \%$ of cocoa fruit is waste. Inthe present study, antioxidant assay (ferric reducing antioxidant power) for cocoa shell was optimized by response surface methodology with three factors and five levels of the model. The factorswere set at solvent percentages (70-90\%), temperatures $\left(45-65^{\circ} \mathrm{C}\right)$, and ultrasound irradiation times (30-60 minutes at a constant frequency of $40 \mathrm{kHz}$. Optimum conditions were established at $70 \%, 65^{\circ} \mathrm{C}$, and 30 minutes respectively, at a concentration of $1.41 \pm 0.01 \mu m o l e s / L$. The analysis of variance (ANOVA)revealed that the coefficient of determination $\left(R^{2}\right)$ was 0.9650 at an optimum concentration of $1.41 \pm 0.01$ umoles $/ L$. Under these conditions, the predicted value was established at1.37, slightly lower than the experimental value. However, the data fit the model with significance at $p<0.0001$ and lack of fit test at $p=0.5091$. The study confirmed that the model equation could be used to predict future observation within the model design range.
\end{abstract}

Index Terms: antioxidant, cocoa shells, ferric reducing antioxidant power, response surface methodology, ultrasound assisted technique.

\section{INTRODUCTION}

Free radicals (FR) such as reactive oxygen and nitrogen species are naturalby-products which are often overproduced in a wide range of biological and chemical systems[1]. They can be classified as unstable chemicals which have one or more free electrons. FR can be produced by different environmental stress factors such as pollution and poor dietary[2].

Revised Manuscript Received on June 22, 2019.

Md Yusof A. H, Malaysia Cocoa Board, Cocoa Innovative and Technology Centre, Lot 12621 Nilai Industrial Area, 71800 Nilai, Negeri Sembilan, Malaysia. Halal Products Research Institue, Universiti Putra Malaysia, Putra Infoport, 43400 Serdang, Selangor, Malaysia.

Abd Gani S. S, Halal Products Research Institue, Universiti Putra Malaysia, Putra Infoport, 43400 Serdang, Selangor, Malaysia. Department of Agriculture Technology, Faculty of Agriculture, Universiti Putra Malaysia, Malaysia

Zaidan U. H, Department of Biochemistry, Faculty of Biotechnology and Biomolecular Sciences, Universiti Putra Malaysia, 43400 Serdang, Selangor, Malaysia

Halmi M. I. E, Department of Land Management, Faculty of Agriculture, Universiti Putra Malaysia, 43400 Serdang, Selangor, Malaysia

Abdul Wahab N, Malaysia Cocoa Board, Cocoa Innovative and Technology Centre, Lot 12621 Nilai Industrial Area, 71800 Nilai, Negeri Sembilan, Malaysia

When free radicals are overproduced, they lead to oxidative stresses, generally defined as imbalance conditions between production of free radicals and their elimination[3].

Some studies suggested that overproduction of FR can lead to inflammatory and other diseases such as cancer[4]. Several types of FR such as hydrogen peroxide, singlet oxygen, hydroxyl radicals, etc.have been documented[5].

In evaluating oxidative stresses, the antioxidant assay is one of the easier methods to measure the ability of an organism to protect itself from free radical. It is known that antioxidant capacity is influenced by several factors such as extraction process, targeted compound, types of natural material and others. The interaction of all these variables is complex.

In analyzing the complex interactions, the response surface methodology (RSM) was utilized in the present study to establish a procedure for future observation. Several types of designs with different levels of observation points can be used to fit the model with the desired independent variables[6]. Besides the Placket Burman factorial design (which is used to evaluate the types of variables chosen)[7], the RSM is a second stage of the technique that is usually used to create a model before another complex model such as artificial neural network be utilized at a later stage[8]. The objective of the model is usually similar, so it can be used to predict the values of independent variables for future observation within the design range[9].

Cocoa shell is one of the waste products being discarded from the cocoa industry. Approximately $75 \%$ of cocoa fruits are wastes or underutilizedby-products. Previous studies have shown that wastes from the cocoa industry have potentials as activated carbon [10] and cosmetics[11,12]. Other studies have also shown that cocoa shell is rich in antioxidant compounds and can be used to fight FR [13]while giving other benefits to human health [14].

In the present study, cocoa shell extract from industrial cocoa was used to determine its antioxidant power by using ferric reducing antioxidant power assay and optimizing the extraction conditions by using three factors and five-levels design. The three variables chosen. were ethanol concentrations $(70-90 \mathrm{v} / \mathrm{v} \%)$, temperatures $\left(45-65^{\circ} \mathrm{c}\right)$, and ultrasound irradiation times (30-60 min).

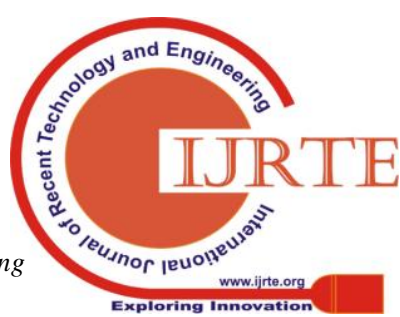




\section{MATERIAL AND METHODS}

Cocoa shell was collected from Pusat Penyelidikan dan Pembangunan Koko (PPPK), Jengka, Pahang, Malaysia.

The cocoa shell waswashed clean and ground using a mechanical grinder (IKA, Staufen Germany) with $1 \mathrm{~mm}$ blade size to fine particles. Other chemicalsused in the study were 2,4,6-tripyridyl-s-triazine (TPTZ), acetate buffer, ferric chloride $\left(\mathrm{FeCl}_{3} \cdot 6 \mathrm{H}_{2} \mathrm{O}\right)$, ferrous sulfate $\left(\mathrm{FeSO}_{4} \cdot 7 \mathrm{H}_{2} \mathrm{O}\right)$ and ethanol. All chemicals were of analytical grades.

\section{A. Ultrasound-assisted Extraction}

One gram of cocoa shell powder was weighed and mixed with $50 \mathrm{~mL}$ ethanol (in various concentrations) in $50 \mathrm{~mL}$ conical flasks and extracted using a sonication bath (Wiseclean, $289 \mathrm{~W}$, Wongju-si, Korea) at $40 \mathrm{kHz}$ frequency, various temperatures, and durations. All experiments are shown in Table 1. Cocoa shell extract was filtered using Watman filter paper (WatmanNo. 4) and the solvent was removed using rotary evaporator (IKA, Staufen, Germany). Water content in the extract was removed by freeze drying (Labconco, Kansas City, MO, USA) at $-80{ }^{\circ} \mathrm{C}$ for 24 hours to get the crude extract. The dried extract was stored at $40^{\circ} \mathrm{C}$ in sample bottles for further analysis.

\section{B. Response Surface Methodology Design (RSM)}

The central composite design (CCD) with three variables and five levels of point observation was chosen for the study. Three variables (ethanol concentrations $(\%), \mathrm{X}_{1}$; temperatures $\left({ }^{\circ} \mathrm{C}\right), \mathrm{X}_{2}$, and ultrasound irradiation time (Min), $\mathrm{X}_{3}$ were chosen as parameters. The maximum (1) and minimum (-1) levels were coded and are shown in Table 1. The alpha value was set at 1.6817 and actual level for alpha was calculated by a software. The ferric reducing antioxidant power (FRAP) was taken as independent variables $(\mathrm{Y})$. The experiment was conducted in triplicates, and all data obtained were determined using the second polynomial equation as in Equation 1. The complex interactions between variables were evaluated using analysis of variance (ANOVA) to determine the value of constant $\beta$ (Equation 1), the coefficient of determination $\left(\mathrm{R}^{2}\right)$, lack of fit, and the significance ofmodel on antioxidants of extract. All data were analyzed using Expert Design Software (version 10, Stat-Ease Inc., Minneapolis, MN, USA).

$$
Y=\beta_{0}+\sum_{i=1}^{3} \beta_{i} X_{i}+\sum_{i=1}^{3} \beta_{i i} X_{i i}^{2}+\sum_{i \neq j=1}^{3} \beta_{i j} X_{i} X_{j}
$$

where,

$\mathrm{Y}$ is the response variables, $\beta_{0}$ is a constant, $\beta_{i}, \beta_{i i}$ and $\beta_{i j}$ are the linear, quadratic and interactive coefficients respectively. $X_{i}$ and $X_{j}$ are the levels of independent variables.

Table. 1 Central composite design of three variables with their observed responses

\begin{tabular}{|c|c|c|c|c|c|c|c|c|}
\hline \multirow[b]{2}{*}{ Run } & \multicolumn{3}{|l|}{ Actual Level } & \multicolumn{3}{|l|}{ Coded Level } & \multirow[b]{2}{*}{$\begin{array}{l}\text { FRAP } \\
\text { Experiment } \\
(\mu \text { moles/L) }\end{array}$} & \multirow[b]{2}{*}{$\begin{array}{l}\text { FRAP } \\
\text { Predict } \\
(\mu \text { moles/L) }\end{array}$} \\
\hline & $\begin{array}{l}\text { Ethanol } \\
\text { Concentration } \\
\mathrm{X}_{1}(\%)\end{array}$ & $\begin{array}{l}\text { Temperature } \\
\mathrm{X}_{2}\left({ }^{\circ} \mathrm{C}\right)\end{array}$ & $\begin{array}{l}\text { Ultrasound } \\
\text { Irradiation } \\
\text { Time } \\
\mathrm{X}_{3} \text { (minutes) }\end{array}$ & $\begin{array}{l}\text { Ethanol } \\
\text { Concentration } \\
\mathrm{X}_{1}(\%)\end{array}$ & $\begin{array}{l}\text { Temperature } \\
\mathrm{X}_{2}\left({ }^{\circ} \mathrm{C}\right)\end{array}$ & $\begin{array}{l}\text { Ultrasound } \\
\text { Irradiation } \\
\text { Time } \\
\mathrm{X}_{3} \text { (minutes) }\end{array}$ & & \\
\hline 1 & 70.00 & 45.00 & 60.00 & -1.00 & -1.00 & 1.00 & $0.99 \pm 0.03$ & 0.96 \\
\hline 2 & 70.00 & 65.00 & 60.00 & -1.00 & 1.00 & 1.00 & $1.26 \pm 0.01$ & 1.17 \\
\hline 3 & 80.00 & 38.18 & 45.00 & 0.00 & -1.62 & 0.00 & $0.28 \pm 0.02$ & 0.36 \\
\hline 4 & 96.82 & 55.00 & 45.00 & 1.62 & 0.00 & 0.00 & $-0.66 \pm 0.01$ & -0.77 \\
\hline 5 & 70.00 & 65.00 & 30.00 & -1.00 & 1.00 & -1.00 & $1.41 \pm 0.01$ & 1.37 \\
\hline 6 & 90.00 & 65.00 & 30.00 & 1.00 & 1.00 & -1.00 & $-0.08 \pm 0.02$ & -0.09 \\
\hline 7 & 80.00 & 55.00 & 45.00 & 0.00 & 0.00 & 0.00 & $0.18 \pm 0.01$ & 0.33 \\
\hline 8 & 80.00 & 55.00 & 45.00 & 0.00 & 0.00 & 0.00 & $0.58 \pm 0.03$ & 0.33 \\
\hline 9 & 80.00 & 55.00 & 70.23 & 0.00 & 0.00 & 1.62 & $0.23 \pm 0.01$ & 0.22 \\
\hline 10 & 80.00 & 71.82 & 45.00 & 0.00 & 1.62 & 0.00 & $0.76 \pm 0.01$ & 0.75 \\
\hline 11 & 90.00 & 45.00 & 60.00 & 1.00 & -1.00 & 1.00 & $-0.23 \pm 0.03$ & -0.24 \\
\hline 12 & 90.00 & 45.00 & 30.00 & 1.00 & -1.00 & -1.00 & $-0.39 \pm 0.02$ & -0.34 \\
\hline 13 & 80.00 & 55.00 & 19.77 & 0.00 & 0.00 & -1.62 & $0.23 \pm 0.01$ & 0.31 \\
\hline 14 & 80.00 & 55.00 & 45.00 & 0.00 & 0.00 & 0.00 & $0.26 \pm 0.01$ & 0.33 \\
\hline 15 & 90.00 & 65.00 & 60.00 & 1.00 & 1.00 & 1.00 & $-0.53 \pm 0.02$ & -0.41 \\
\hline 16 & 80.00 & 55.00 & 45.00 & 0.00 & 0.00 & 0.00 & $0.46 \pm 0.01$ & 0.33 \\
\hline 17 & 70.00 & 45.00 & 30.00 & -1.00 & -1.00 & -1.00 & $0.93 \pm 0.02$ & 0.83 \\
\hline 18 & 80.00 & 55.00 & 45.00 & 0.00 & 0.00 & 0.00 & $0.23 \pm 0.01$ & 0.33 \\
\hline 19 & 80.00 & 55.00 & 45.00 & 0.00 & 0.00 & 0.00 & $0.29 \pm 0.01$ & 0.33 \\
\hline 20 & 63.18 & 55.00 & 45.00 & -1.62 & 0.00 & 0.00 & $1.30 \pm 0.04$ & 1.48 \\
\hline
\end{tabular}

Table. 2 Conditions for ramp function graph

\begin{tabular}{|c|c|c|c|c|c|c|}
\hline $\begin{array}{l}\text { Ramp } \\
\text { Function }\end{array}$ & $\begin{array}{l}\text { Ethanol } \\
\text { Concentration } \\
\mathrm{X}_{1}(\%)\end{array}$ & $\begin{array}{l}\text { Temperature } \\
\mathrm{X}_{2}\left({ }^{\circ} \mathrm{C}\right)\end{array}$ & $\begin{array}{l}\text { Ultrasound } \\
\text { Irradiation Time } \\
\mathrm{X}_{3} \text { (minutes) }\end{array}$ & Desirability & $\begin{array}{l}\text { FRAP } \\
\text { Experiment } \\
(\%) \\
\end{array}$ & $\begin{array}{l}\text { FRAP } \\
\text { Predict } \\
(\%) \\
\end{array}$ \\
\hline 1 & 73.83 & 69.74 & 19.77 & 1.00 & $1.30 \pm 0.05$ & 1.38 \\
\hline 2 & 85.78 & 58.01 & 19.77 & 1.00 & $0.05 \pm 0.01$ & 0.04 \\
\hline 3 & 66.11 & 40.04 & 40.52 & 1.00 & $1.10 \pm 0.0$ & \\
\hline
\end{tabular}




\section{Determination of ferric reducing antioxidant power (FRAP) of cocoa shell extract.}

The concentrations of FRAP in cocoa shell extract were determined using procedures of Azizah Othman et al. (2007) and Benzie and Strain(1996) [15,16]. The ratio for FRAP reagent used was 10:1:1.Acetate buffer of $300 \mathrm{mM}(\mathrm{pH} 3.6)$ was mixed with, $10 \mathrm{mM}$ TPTZ and $20 \mathrm{mM} \mathrm{FeCl}^{3} \cdot 6 \mathrm{H}_{2} \mathrm{O}$ at $37 \circ \mathrm{C}$ and kept as a stock solution. Approximately $3 \mathrm{~mL}$ of FRAP reagent from the stock solution was mixed with 100 $\mu \mathrm{L}$ of sample or calibration standard. About $300 \mu \mathrm{L}$ water was then added. The mixture was then incubated at $37{ }^{\circ} \mathrm{C}$ for 10 minutes. Absorbance was measured at $593 \mathrm{~nm}$ by using UV-Visible Spectrophotometer (Cary 60, Agilent Technologies, Santa Clara, CA, USA). The FRAP value was calculated using a calibration curve constructed from $\mathrm{FeSO}_{4} \cdot 7 \mathrm{H}_{2} \mathrm{O}(7.8-1000 \mu \mathrm{g} / \mathrm{mL})$, with $\mathrm{R}^{2}=0.9928$.

\section{Ramp function and T-test}

The value of constant $\beta$ obtained for the FRAP on cocoa shell extract was tested by using a ramp function as shown in Table 2 to test its effectiveness with desirability 1 . The desirability number chosen near 1 or 1 shows that the independent variable (Y) will be comparable to the experimental value as reported by Josh L. Pilkington (2014) [17]. The values obtained from the study were then analyzed by using T-test to find its p-value by software Minitab (Version14, Minitab, Pennsylvania, USA).

\section{E. Statistical analysis}

All data collected were expressed as a mean \pm standard error. Statistical analysis was evaluated by analysis of variance (ANOVA) on Expert Design software and the data obtained from the ramp function were analysed by using $\mathrm{T}$ test on Minitab Software.

\section{RESULTS AND DISCUSSION}

\section{A. Fitting the Model}

The fitting of the model to the polynomial equation can be determined from the lack of fit test with insignificant value and significant $\mathrm{p}$-value in the interaction between variables in the model. All data collected from the treatments were evaluated using ANOVA as shown in Table 3. The model and lack of fit test showed significant and non-significant at $p<0.001$ and $p>0.5091$ with F-values of 30.67 and 0.98 respectively. The single interaction in the model for solvent concentration, $\mathrm{X}_{1}$ and temperature, $\mathrm{X}_{2}$ showed significance at $\mathrm{p}<0.0001$ and $\mathrm{p}<0.05$, respectively. The complex interaction between the variables was evaluated to determine the constant value of $\beta$ as in Equation 2:

$$
\begin{aligned}
Y_{\text {FRAP }}=1.52153 & -0.022915 X_{1}+0.027993 X_{2} \\
& +0.060017 X_{3}-0.000910558 X_{1} X_{2} \\
& -0.00018199 X_{1} X_{3}-0.00069425 X_{2} X_{3} \\
& +0.0000905191 X_{1}^{2}+0.000795830 X_{2}^{2} \\
& -0.000100987 X_{3}^{2}
\end{aligned}
$$

\begin{tabular}{|c|c|c|c|c|c|}
\hline Source & $\begin{array}{l}\text { Sum of } \\
\text { square }\end{array}$ & $\mathrm{DF}$ & $\begin{array}{l}\text { Mean } \\
\text { square }\end{array}$ & $\begin{array}{l}\text { F- } \\
\text { value }\end{array}$ & $\begin{array}{l}\mathrm{P}- \\
\text { value }\end{array}$ \\
\hline Model & 6.53 & 9 & 0.73 & 30.67 & $\begin{array}{l}< \\
0.0001\end{array}$ \\
\hline $\mathrm{X}_{1}$ & 6.08 & 1 & 6.08 & 256.85 & $\begin{array}{l}< \\
0.0001\end{array}$ \\
\hline $\mathrm{X}_{2}$ & 0.18 & 1 & 0.18 & 7.57 & 0.0205 \\
\hline $\mathrm{X}_{3}$ & 0.010 & 1 & 0.010 & 0.43 & 0.5277 \\
\hline $\mathrm{X}_{1}^{2}$ & 0.001181 & 1 & 0.001181 & 0.050 & 0.8277 \\
\hline $\mathrm{X}_{2}^{2}$ & 0.091 & 1 & 0.091 & 3.86 & 0.0779 \\
\hline $\mathrm{X}_{3}^{2}$ & 0.007440 & 1 & 0.007440 & 0.31 & 0.5873 \\
\hline $\mathrm{X}_{1} \mathrm{X}_{2}$ & 0.066 & 1 & 0.066 & 2.80 & 0.1250 \\
\hline $\mathrm{X}_{1} \mathrm{X}_{3}$ & 0.005962 & 1 & 0.005962 & 0.25 & 0.6265 \\
\hline $\mathrm{X}_{2} \mathrm{X}_{3}$ & 0.087 & 1 & 0.087 & 3.67 & 0.0845 \\
\hline Residual & 0.24 & 10 & 0.024 & - & - \\
\hline Lack of fit & 0.12 & 5 & 0.023 & 0.98 & 0.5091 \\
\hline $\begin{array}{l}\text { Pure } \\
\text { error }\end{array}$ & 0.12 & 5 & 0.024 & - & - \\
\hline
\end{tabular}

Table. 3 Analysis of variance for a fitted quadratic model of FRAP from cocoashell extract.

\section{B. Response surface analysis of FRAP}

The surface of the RSM graph interaction between two variables was almost similar (Figures 1 until 3). The p-value for interaction between variables was insignificant, except linear interaction which showed significant difference at $\mathrm{p}>$ 0.05 . The antioxidant assay showed that only concentration of ethanol and temperature gave significant impact on the model. However, when these two variables interacted with each other in terms of linear and square, only linear the interactions gave an impact to the independent variables.

From the present experiment, the FRAP concentration increased along with ethanol concentration until the positive alpha value (96.82\%). Other previous studies showed that using solvent in the extraction process can increase the amount of antioxidant compounds extracted compare to water extraction [18].Using solvent mixture 1 increased extraction yield of an antioxidant compound as the mixture solvent extracted from both ends of the polarity of the compound [19]. Previous studiesshowed that polar solvent exhibited highamount of bioactive compounds and the mixture of the solvent with water can increase the extraction of the bioactivecompounds and optimized at $80.87 \%$ of concentration methanol [20]. 
Optimization of Central Composite Design of Ferric Reducing Antioxidant Power from Cocoa (Theobroma cacao) Shell Using Ultrasound-assisted Technique

Table. 4 T-test table of verification of the model

\begin{tabular}{|c|c|c|c|c|c|c|c|}
\hline $\begin{array}{l}\text { Ramp } \\
\text { function }\end{array}$ & $\begin{array}{l}\text { Number of } \\
\text { Samples }\end{array}$ & Mean & $\begin{array}{l}\text { Standard } \\
\text { deviation }\end{array}$ & $\begin{array}{l}\text { Standard } \\
\text { error }\end{array}$ & $\begin{array}{l}95 \% \text { Coefficient } \\
\text { of the interval }\end{array}$ & T-value & P-value \\
\hline 1 & 3 & 1.3042 & 0.0443 & 0.0256 & $1.23,1.45$ & -1.46 & 0.282 \\
\hline 2 & 3 & 0.0461 & 0.0049 & 0.0028 & $0.03,0.05$ & 3.896 & 0.060 \\
\hline 3 & 3 & 1.0964 & 0.0805 & 0.0465 & $0.89,1.29$ & 1.2 & 0.354 \\
\hline
\end{tabular}

Another study was done by Mariel Gullian et al. (2017) on radical scavenging activity from Brosimum alicastrum showed the same resultswhen the solvent concentration was at $80 \%$ by using Ben-Behnken design [21].

In chemical and biochemical reactions, the presence of temperature increases the process of extraction as temperature decreases polarity of the targeted natural compounds and reduces thermal resistant of the targeted cell in natural material [22,23]. The previous studies also showedthat the range of targeted antioxidant compound such as polyphenols and phenolic compound were between $45^{\circ} \mathrm{C}$ and $65{ }^{\circ} \mathrm{C}$ since the compounds can be degraded due to high thermal processes[24,25]. In a study by Nur Fauwizah et al. (2017) on flavonoid compounds from Curcuma zedoaria leaves, with conditions optimized by using RSM at $75{ }^{\circ} \mathrm{C}$ [26],the finding showed that antioxidant can be optimized above $65{ }^{\circ} \mathrm{C}$ due to the different types of the conditions of extraction set and types of natural materials.

Although the analysis showed insignificant differences in temperature and duration in the process of extraction, one of the variables should change its level value. The previous study showed that ultrasound can be optimized at a duration of less than 35 minutes since the extraction process was enhanced by ultrasound [27] and the compound decreased at longer treatment as described by Jose R. et al. (2012) [28]. The different data gathered by the previous study showed that there were other factors that exerted influence during extraction process. The non-similar results on antioxidant occurred due to many factors such as type of antioxidant assay, type of natural material, process of extraction, type of solvents used, the range of the model, etc.[29].

Another antioxidant assay by using CCD (Unpublished data) showed that the range set for the design, gave significant effects on the types of targeted antioxidant compound chosen. The scavenging effect of the compound to the free radical and bleaching effect of the antioxidant compound were comparable to the BHT compound. Another study on tyrosinase enzyme showed that the antioxidant compound in the MSCE was comparable to acid ascorbic.

\section{Verification of model}

The model obtained from the experiment was verified by comparing the values obtained from the different conditions set through ram function and evaluated the data obtained through T-test. The desirability from the model were given from 0 to 1 in a range. The highest desirability value show the more likely the data get from the experiment were comparable to the predicted value hence it can reduced the standard error between the data. From the table 2 the ethanol concentration were set to three level of ramp function which was low concentration (66.11\%), medium concentration $(73.83 \%)$ and high concentration $(85.78 \%)$ followed by the same level set to the temperature condition. The ultrasound irradiation time were set in a range from least value to the most value base on the model Three condition with desirability value 1 were selected from 100 condition created by the software as a simulator to test the model equation. From the T-test, the value of $p$ showed significance when the data were compared as event the desired value were set to the highest (desirability 1was chosen).The $\mathrm{p}$-value of ramp function 1 until 3 showed nonsignificance $(p>0.05)$ as shown in Table 4 , between the predictive value and the experimental value. Therefore the polynomial equation build can be used to predict future observation and comparability as long the desirability were set to 1 .

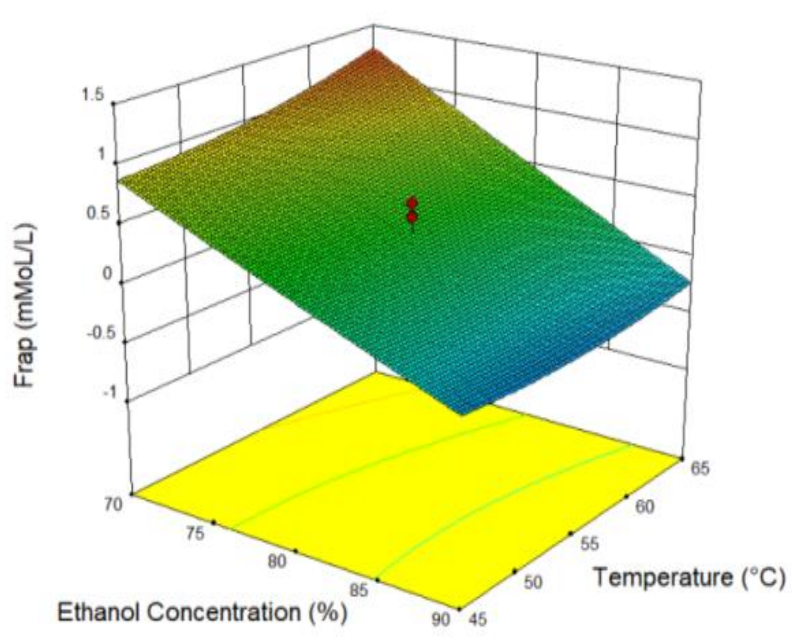

Fig. 1 Response surface plot and of ethanol concentration $\left(X_{1}\right)$ and Temperature $\left(X_{2}\right)$

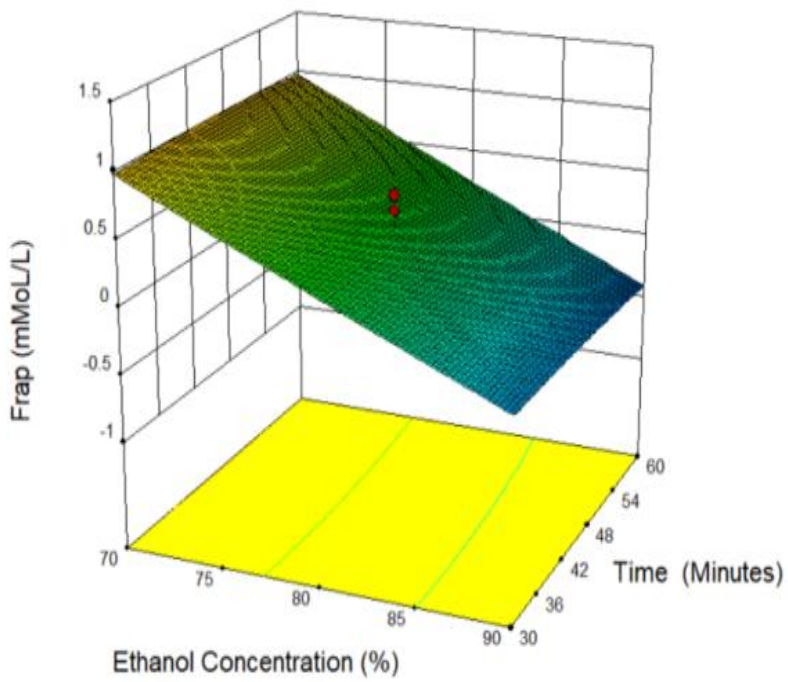

Fig. 2 Response surface plot of ethanol concentration $\left(X_{1}\right)$ and Ultrasound irradiation time $\left(X_{3}\right)$ 


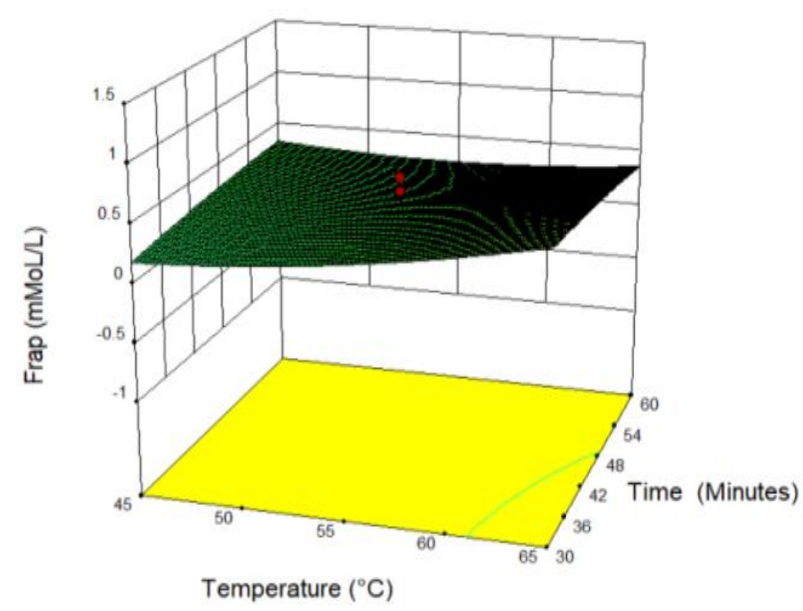

Fig. 3 Response surface plot of temperature $\left(X_{2}\right)$ and Ultrasound irradiation time $\left(\mathbf{X}_{3}\right)$

\section{CONCLUSION}

The RSM was used to evaluate the complex interaction between variables in the extraction process to establish the capability of the antioxidant power from coco shell extract. The effect of coco shell extract on antioxidant power was optimized by using RSM. From the experiment, the results show that the model was significant $\mathrm{p}<0.0001$. The lack of fit test shows non-significance $(p>0.05)$ between interaction of the variables to the design range set for the model. The equation built from the model can be repeated within the design range. From the model, the optimization conditions are ethanol concentration of $70 \%$, temperature $65{ }^{\circ} \mathrm{C}$, ultrasound irradiation time 30 minutes. Under these conditions, the experimental FRAP is $1.41 \pm 0.01 \mu$ moles/L, and the predicted value is $1.37 \mu$ moles/LThe study suggests the extraction of cocoa shell was successfully optimized and can be predicted for future observation within the design range.

\section{ACKNOWLEDGMENT}

This work was supported by Malaysia Cocoa Board, Halal Product Research Institute, and Universiti Putra Malaysia (UPM).

\section{REFERENCES}

1. R. Mittler, ros are good trends. Plant sci. 22 (2017) 11-19. doi:10.1016/j.tplants.2016.08.002.

2. I. Romieu, N. Kunzli, J. Sunyer, Air pollution, oxidative stress and dietary supplementation: A Review, 31 (2008) 179-196. doi:10.1183/09031936.00128106.

3. S. Reuter, S.C. Gupta, M.M. Chaturvedi, B.B. Aggarwal, Oxidative stress, inflammation, and cancer: How are they linked?, Free Radic. Biol. Med. $49 \quad$ (2010) 1603-1616. doi:10.1016/j.freeradbiomed.2010.09.006.Oxidative.

4. M. Goodman, R.M. Bostick, O. Kucuk, D.P. Jones, Clinical trials of antioxidants as cancer prevention agents: Past, present, and future, Free Radic. Biol. Med. $51 \quad$ (2011) 1068-1084. doi:10.1016/j.freeradbiomed.2011.05.018.

5. E.A. Sisein, Biochemistry of free radicals and antioxidants, Biosciences. 2 (2014) 110-118.

6. M. Xu, Q. Shao, S. Ye, S. Li, M. Wu, M. Ding, Y. Li, Simultaneous extraction and identification of phenolic compounds in Anoectochilus roxburghii using microwave-assisted extraction combined with UPLCQ-TOF-MS/MS and their antioxidant activities, Front. Plant Sci. 8 (2017) 1-11. doi:10.3389/fpls.2017.01474
7. S. Goktas, M.D. Köse, O. Bayraktar, A screening experimental design to develop high extraction yield of flavonoids in Ginkgo biloba Leaves, 39 (2017) 33-39

8. A.I. Khuri, A General overview of Response Surface Methodology, Biometrics Biostatisitics Int. J. 5 (2017) $1-8$ doi:10.15406/bbij.2017.05.00133

9. R. V Lenth, Response-Surface Methods in R , using RSM, Journalof Stat. Softw. 32 (2009)1-4. doi:http://dx.doi.org/10.18637/jss.v032.i07

10. F. Ahmad, W.M.A.W. Daud, M.A. Ahmad, R. Radzi, Cocoa (Theobroma cacao) shell-based activated carbon by $\mathrm{CO} 2$ activation in removing of cationic dye from aqueous solution: Kinetics and equilibrium studies, Chem. Eng. Res. Des.90 (2012) 1480-1490. doi:10.1016/j.cherd.2012.01.017.

11. A.A. Karim, A. Azlan, A. Ismail, P. Hashim, N.A. Abdullah, Antioxidant properties of cocoa pods and shells, Malaysian Cocoa J. 8 (2014).

12. A. Abdul Karim, A. Azlan, A. Ismail, P. Hashim, S.S. Abd Gani, B.H. Zainudin, N.A. Abdullah, Phenolic composition, antioxidant, antiwrinkles and tyrosinase inhibitory activities of cocoa pod extract, BMC Complement. Altern. Med. 14 (2014) 1-13. doi:10.1186/1472-688214-381

13. E. Lecumberri, R. Mateos, M. Izquierdo-Pulido, P. Rupérez, L. Goya, L. Bravo, Dietary fibre composition, antioxidant capacity and physicochemical properties of a fibre-rich product from cocoa (Theobroma cacao L.), Food Chem. 104 (2007) 948-954. doi:10.1016/j.foodchem.2006.12.054.

14. M.J. Mitchell, M.R. King, Polyphenols and aging, 3 (2014) 1-23. doi:10.1088/1367-2630/15/1/015008.Fluid.

15. A. Othman, A. Ismail, N. Abdul Ghani, I. Adenan, Antioxidant capacity and phenolic content of cocoa beans, (2007) 1523-1530. doi:10.1016/j.foodchem.2005.12.021.

16. I.F.F. Benzie, J.J. Strain, the ferric reducing ability of plasma ( FRAP ) as a measure of "“ Antioxidant Power "”: The FRAP Assay, Anal. Biochem. 76 (1996) 70-76.

17. J.L. Pilkington, C. Preston, R.L. Gomes, Comparison of response surface methodology (RSM) and artificial neural networks (ANN) towards efficient extraction of artemisinin from Artemisia annua, Ind. Crops Prod. 58 (2014) 15-24. doi:10.1016/j.indcrop.2014.03.016.

18. Z. Hromádková, Z. Košt'álová, A. Ebringerová, Comparison of conventional and ultrasound-assisted extraction of phenolics-rich heteroxylans from wheat bran, Ultrason. Sonochem.15(2008)10621068. doi:10.1016/j.ultsonch.2008.04.008.

19. A. Thouri, H. Chahdoura, A. El Arem, A.O. Hichri, R. Ben Hassin, L. Achour, Effect of solvents extraction on phytochemical components and biological activities of Tunisian date seeds ( var . Korkobbi and Arechti ), (2017) 1-10. doi:10.1186/s12906-017-1751-y

20. H. Zhang, G. Xie, M. Tian, Q. Pu, M. Qin, Optimization of the ultrasonic-assisted extraction of bioactive flavonoids from Ampelopsis grossedentata and subsequent separation and purification of two flavonoid aglycones by high-speed counter-current chromatography, Molecules. 21 (2016) 1-17. doi:10.3390/molecules21081096

21. Mariel G. Klanian, MontserratTerrats Preciat, Optimization of the Ultrasound-Assisted Extraction of Phenolic Compounds from $\begin{array}{lllll}\text { Brosimum alicastrum, } & \text { Molecules. } 22 \quad \text { (2017) } & 1286\end{array}$ doi:10.3390/molecules22081286.

22. T.D. Kim, H.J. Ryu, H. Il Cho, C. Yang, J. Kim, Thermal Behavior of Proteins: Heat-Resistant Proteins and Their Heat-Induced Secondary Structural Changes $\dagger$, Biochemistry. 39 (2000) 14839-14846

23. A.C. Benniston, A. Harriman, J.P. Rostron, The effect of solvent polarity on the photophysical properties of 4-cyano-(4 0 methylthio)diphenylacetylene: A prototypic donor-acceptor system w, (2005) 3041-3047.

24. G. Pan, G. Yu, C. Zhu, J. Qiao, Ultrasonics Sonochemistry Optimization of ultrasound-assisted extraction ( UAE ) of flavonoids compounds ( FC ) from hawthorn seed ( HS ), Ultrason. Sonochemistry. $\quad 19 \quad$ (2012) doi:10.1016/j.ultsonch.2011.11.006.

25. P.Z. Ma, L.D. Diamanto, A. Cvetanovi, Optimization of the Extraction Process of Antioxidants from Orange Using Response Surface Methodology, (2016) 1436-1443. doi:10.1007/s12161-015-0321-5. 
26. N.F. Azahar, S. Salwa, A. Gani, N. Fadzillah, M. Mokhtar, Optimization of phenolics and flavonoids extraction conditions of Curcuma Zedoaria leaves using response surface methodology, Chem. Cent. J. (2017) 1-10. doi:10.1186/s13065-017-0324-y.

27. S. Jang, A.Y. Lee, A.R. Lee, G. Choi, H. Kyoung, Optimization of ultrasound-assisted extraction of glycyrrhizic acid from licorice using response surface methodology, Integr. Med. Res. 6 (2017) 388-394. doi:10.1016/j.imr.2017.08.003.

28. J.R. Vergara-salinas, J. Perez-Jimenez, J.L. Torres, E. Agosin, J.R.P. Correa, Effects of Temperature and Time on Polyphenolic Content and Antioxidant Activity in the Pressurized Hot Water Extraction of Deodorized Thyme ( Thymus vulgaris ), Agric. Food Chem. 60 (2012) 10920-10929. doi:10.1021/jf3027759.

29. S.J.S. Flora, Structural, chemical and biological aspects of antioxidants for strategies against metal and metalloid exposure. Oxid. Med. Cell. Longev. 2 (2009) 191-206. doi:10.4161/oxim.2.4.9112 